\title{
The identification and classification of green areas for urban planning using multispectral images at Baja California, Mexico
}

\author{
C. Peña-Salmón ${ }^{1}$, O. Leyva-Camacho ${ }^{1}$, R. Rojas-Caldelas ${ }^{1}$, \\ A. Alonso-Navarrete ${ }^{2} \&$ P. Iñiguez-Ayón ${ }^{1}$ \\ ${ }^{1}$ Faculty of Architecture and Design, \\ Universidad Autónoma de Baja California, México \\ ${ }^{2}$ Division of Science and Arts for Design, \\ Universidad Autónoma Metropolitana, México
}

\begin{abstract}
In the legal framework of urban planning in Mexico, the provision of urban green areas is approached from a social perspective, as public spaces for recreation and sports activities, regardless of the environmental and economic benefits they can provide from a sustainable development perspective. The planning of urban green areas requires a set of conditions in order to be successful, among which are: an updated regulatory framework, adequate financial resources, technical knowledge of the appropriate plant species and the effective participation of the community. However, without a complete and classified inventory of the existing green areas, any planning is unfeasible. Therefore, this paper presents the first stage of the study of urban green areas in a city of the State of Baja California, Mexico, developing firstly, a review of the regulatory framework and a redefinition of the concept of urban green areas that takes into account the basic dimensions of sustainability, and on the other hand, it proposes a general classification of urban green areas that includes all types of open spaces with vegetation: both for public and private use, subdivided into systems and subsystems, which were the basis for the identification, classification and quantification of urban green areas, using Quickbird multispectral images of $2.6 \mathrm{~m}$ resolution and applying the Normalized Difference Vegetation Index (NDVI) using IDRISI software, and data were integrated in a GIS; finally, the results and discussion are presented.
\end{abstract}

Keywords: green areas typology, GIS, multispectral imaging, sustainability. 


\section{Introduction}

Urban green areas provide a wide range of benefits to city inhabitants and they can contribute to a sustainable urban development because of the multiple roles they can play from the environmental, social and economic perspectives.

From the environmental viewpoint, urban green areas can improve microclimatic conditions in outdoor spaces and help restore physical comfort; improve air quality by providing oxygen and removing carbon dioxide, which is a greenhouse gas, and so help mitigate the climate change [1-3]; reduce soil erosion by wind or water; and become a support for wildlife habitat and therefore promote biodiversity [4].

From the perspective of their contribution to social welfare, green areas constitute the open spaces par excellence that the population uses for recreation and outdoor sports activities; they also support the physical and mental health of the population, help reduce stress [5, 6], as well as to improve the quality of the urban image of the city and strengthen the identity of places, given the aesthetic, symbolic and heritage values of vegetation. Also, according to McPherson and Johnson [7], these spaces can reinforce the social identity and sense of community through participation in afforestation programs.

From the economic point of view, green areas can increase the value of land and adjacent properties [8], raise the sales of stores located on forested streets aesthetically maintained [9], and it can reduce the cost and consumption of energy in buildings through shading. Also, green areas can represent a source of income as an urban agriculture activity [10].

Yet despite the many functions and benefits provided by various forms of green areas to the welfare of the population in cities, only their social function exclusively referred to the spaces for recreational activities and sports is considered in urban planning processes, minimizing their environmental and economic benefits and thus the opportunity for a greater contribution to urban sustainability.

Under this view, the planning of urban green areas is partial and inadequate; therefore, we need a conceptual redefinition that allows to carry out an inventory and characterization of all types of urban green areas, considering that all surface covered with vegetation performs an environmental service, in addition to its contribution to the social welfare of the population and the economic value that can be generated.

Therefore, this study aims to present a method to identify and classify - using multispectral images - all open spaces with vegetation in the city, for both public and private use, by classifying them into systems and subsystems. First, the names given to green areas under Mexican law are analyzed, and a green areas typological proposal is made. Thereafter, the stages of the process for the identification and classification of green areas using satellite imagery are described, and the proposed method is applied in a Baja California city. Finally, the results of the study are presented and discussed. 


\section{Urban green areas in the regulatory framework}

Under Mexican law there is no a specific law on green areas planning, but the regulatory framework on such areas is scattered in the set of federal, state and municipal laws and regulations regarding urban development and the environment. Under federal law, the term green areas is generally referenced, but not defined; it is in the regulations where more specific considerations are contemplated. Given the large number of existing regulations, there is no unique concept or definition, but a diversity of meanings according to each regulation.

According to Miyasako [11], green areas have different names under Mexican law, which has caused that they are not given concrete relevance; they have been considered primarily as parks and gardens under the Constitution of the United Mexican States and federal laws related primarily to issues of urban development and environment.

In the preparation of urban development programs for human settlements, green areas are considered as public services, and its planning is governed, in addition to state laws and municipal regulations, by the Sistema Normativo de Equipamiento Urbano (Regulatory System of Urban Equipment) developed by Sedesol [12], which is the set of regulations that concerns the supply of social urban public services, focused on recreation and sports, as essential elements for the development of the community, since they contribute to the physical and mental well-being of the citizens.

Recreation and sports public services are grouped into a subsystem, and is composed of eight different elements for recreation and seven for sports, its resources being defined by the service area established from a regional level to a neighborhood level.

In the legal framework of the State of Baja California, there are different meanings for green area according to the regulations. It may be considered an asset of common use, a donation area, a conservation area or a recreation area. However, the only regulation that establishes an obligation to create green areas through donation is the Reglamento de Fraccionamientos del Estado de Baja California (Regulation of Housing Development Areas of the State of Baja California) [13], which determines the donation of $3 \%$ of the salable area of housing developments to create parks or gardens.

Under the various municipal regulations of green areas, there are different definitions but they all agree in that they are areas of public use, consisting of vegetation, represented by gardens, parks, roadsides, roundabouts, sidewalks, roads, sports fields and ecologic preservation zones [14-16]. Except for ecological preservation zones that have an environmental function, the rest of the elements have a social function, either as recreational and sports areas or aesthetic elements that improve the urban image of the city.

In short, under the regulations related to urban planning, green areas are primarily considered public open space where recreation and sports activities are performed, excluding other public spaces such as areas around educational or administrative buildings, health centers, etc., as well as all private open spaces. 
Therefore, it is necessary to have a broader conception integrating all kinds of green areas, both for public and private use, that allows to incorporate the participation of the entire population to ensure the success of afforestation policies and programs; so based on Peña [17], the definition of urban green area proposed and adopted in this study is: Any public or private open area located within the urban and/or suburban areas, provided predominantly with vegetation whether of natural or manmade origin, that can be used for environmental, social or productive functions. The following classification of green areas grouped by type, system and subsystem will be adopted (Table 1).

Table 1: Proposed typology of urban green areas.

\begin{tabular}{|c|c|c|}
\hline Type & System & Subsystem \\
\hline \multirow{6}{*}{ Public } & \multirow{3}{*}{ Green Areas for public services } & Recreation \\
\hline & & Sports \\
\hline & & Other public services \\
\hline & Functional Green Areas & Roads \\
\hline & \multirow{2}{*}{ Natural and Protected Green Areas } & Natural \\
\hline & & Protected \\
\hline \multirow{6}{*}{ Private } & \multirow{4}{*}{ Productive Green Areas } & Agriculture and livestock \\
\hline & & Industrial \\
\hline & & Commercial \\
\hline & & Touristic \\
\hline & \multirow[b]{2}{*}{ Private Green Areas } & Housing \\
\hline & & $\begin{array}{c}\text { Other subsystems of } \\
\text { private access }\end{array}$ \\
\hline
\end{tabular}

\section{Methodology}

The process for the identification and classification of urban green areas was performed using QUICKBIRD multispectral satellite imagery on March 25, 2003 with a $2.6 \mathrm{~m}$ resolution and UTM WGS84 projection. The software used was: IDRISI for image processing; and MapInfo for construction of GIS. The procedure for the identification and classification of urban green areas was developed in eight stages:

\section{a. Import spectral bands from TIFF file format to RST}

To analyze the images with the IDRISI software it was necessary to import the spectral bands, blue (b1), green (b2), red (b3) and near infrared (b4) from TIFF file format of the original QUICKBIRD images to RST file format.

\section{b. Composition of image in natural color}

For a natural color image, the bands b1, b2 and b3 were integrated with the IDRISI software (Figure 1). 


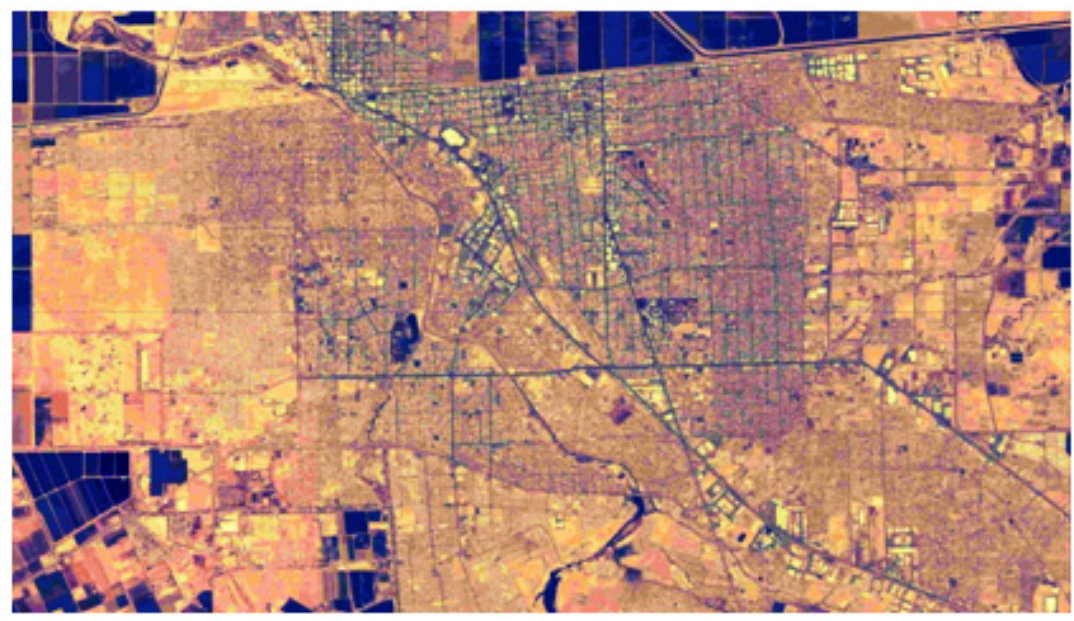

Figure 1: Natural color image of Mexicali City.

\section{c. Image processing function with NDVI (Normalized Difference Vegetation Index)}

The red band (b3) and infrared band (b4) that collect the amount of red energy that is absorbed by chlorophyll of plants and the amount of near-infrared energy that is reflected by the cellular structure of the leaf, were processed with the NDVI, to identify the vegetation cover, and the formula is (b4 - b3)/ (b4 + b3). This index has the advantage that its variation is from -1 to 1 , any positive value above zero representing the presence of vegetation given its photosynthetic activity [18]. This study considers digital number (DN) and not reflectance, because the important thing was to identify and differentiate the vegetation from other covers types (Figure 2).

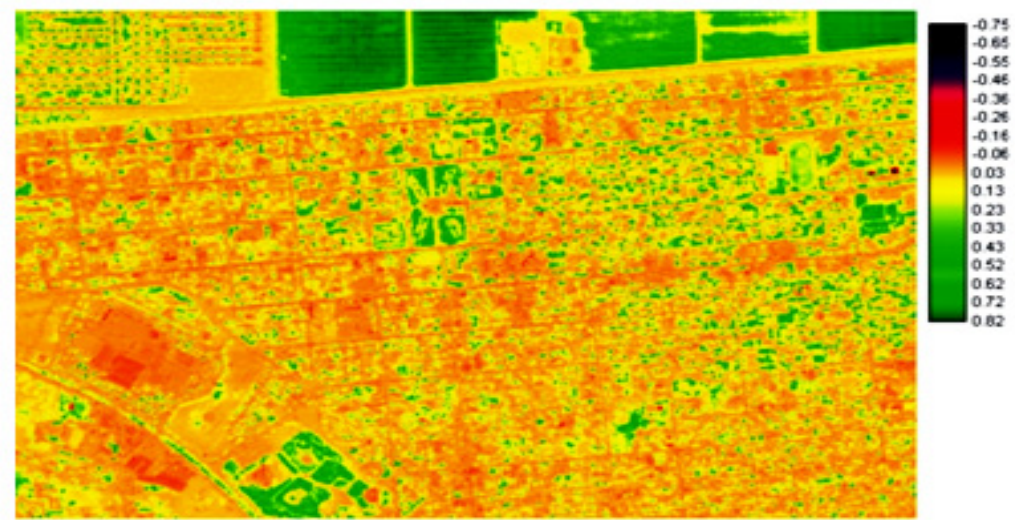

Figure 2: NDVI image of a section of the city. 


\section{d. Reclassification of data to form a binary image}

Once the green areas were identified through the NDVI, we selected all positive values that indicate a photosynthetic activity and values were reclassified into a new category to create a binary image. Values less than 0.03 were grouped into class 0 and values in the range of 0.03 to 0.82 were grouped in class 1 . (Figure 3 ).

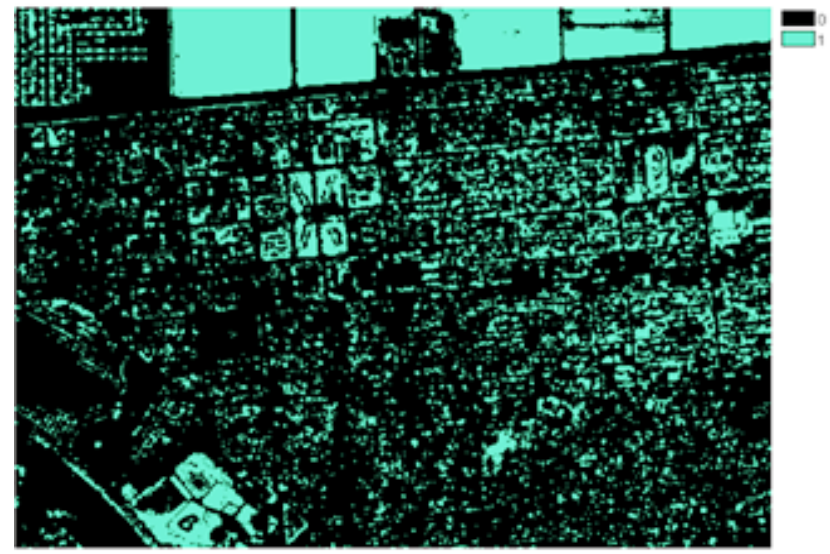

Figure 3: Binary image of the vegetation cover.

\section{e. Conversion of raster to vector format from binary image}

Once the binary image was obtained it was converted from raster to vector format, obtaining polygons greater of $6 \mathrm{~m}^{2}$ of all surfaces that had a value of 1 , corresponding to vegetation (Figure 4).

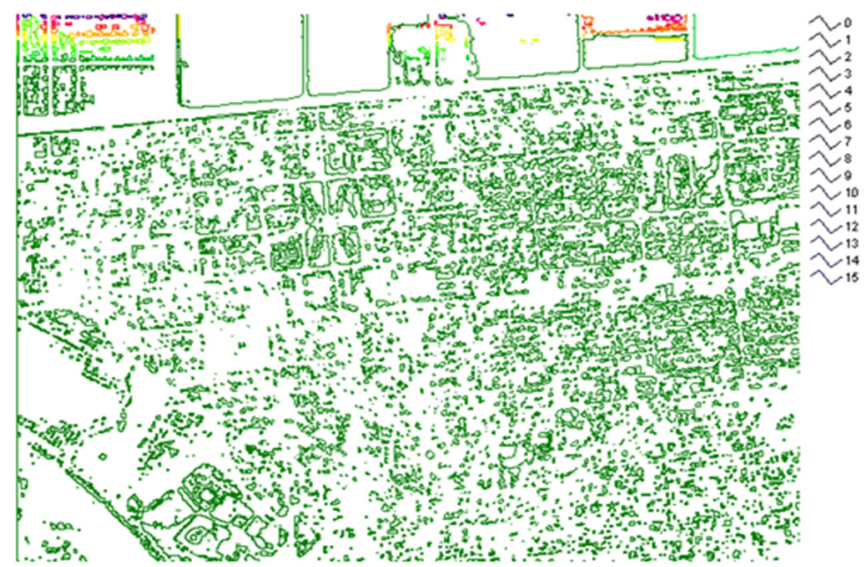

Figure 4: Vectorization of green areas from binary image. 


\section{f. Verification of the accuracy of polygons on the image of natural color}

The polygons of vegetation cover were superimposed on the image of natural color to check the accuracy, considering 3 ranges: 0.06 to 0.82 ; from 0.14 to 0.82 and from 0.20 to 0.82 ; and the range with the best accuracy was from 0.20 to 0.82 (Figure 5). Thereafter, training samples at specific sites were performed to validate the information.

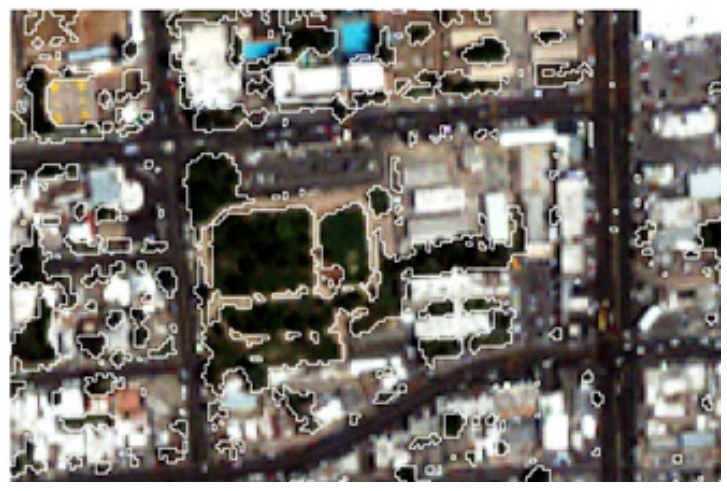

Figure 5: Superposition of polygons with natural color image, range from 0.20 to 0.82 .

\section{g. Classification of vegetation covers by urban land use}

To obtain the different types of green areas per subsystem, polygons were superimposed over the layout of urban land use plan prepared by the Instituto Municipal de Investigación y Planeación Urbana (Municipal Institute for Research and Urban Planning) (IMIP) [19], to determine the green areas associated with nine uses: housing, trade and services, storage and services, industrial, parks and gardens, mixed, urban corridor and conservation areas (Figure 6).
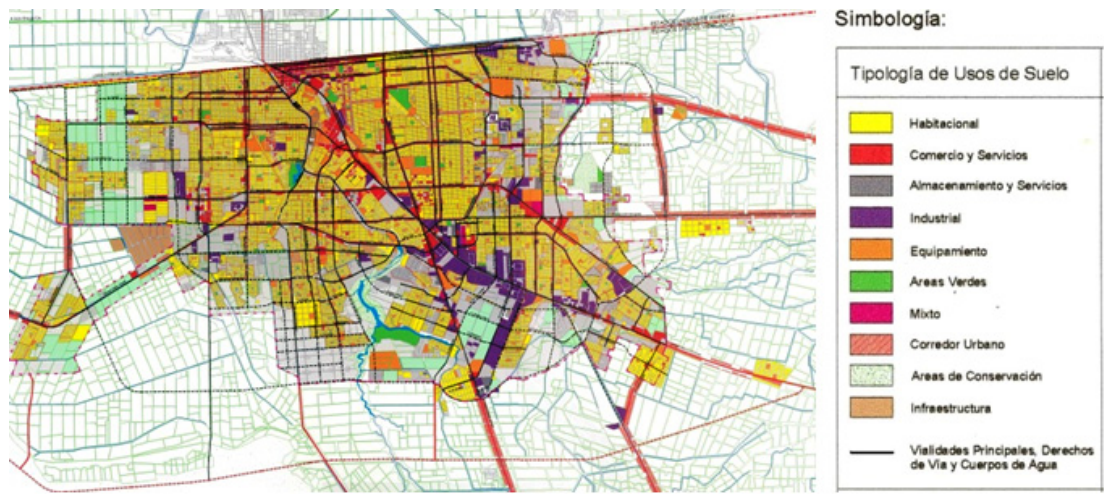

Figure 6: Urban land uses in Mexicali, 2005. 


\section{h. Integrating information in a GIS}

The Mapinfo program was used for the development of a Geographical Information System (GIS), integrating the green areas classified by subsystems, the mapping by land lots, and two databases: an inventory of neighborhood gardens, roundabouts and roadsides performed by the municipality in 2004 [20], and a 2005 database of the State Government of Baja California of schools [21], comprising public and private schools with preschool, elementary, middle and high school levels.

\section{Results and discussion}

The urban green areas identification process was conducted for the city of Mexicali, considering the typology of green areas proposed at subsystem level, based on the IMIP urban land use layout. 197,587 polygons of green areas were identified in total, which were then classified into five systems and ten subsystems. The total area of the city's vegetation cover was $28,943,211.71 \mathrm{~m}^{2}$, representing $13.88 \%$ of the total urban area. The largest percentage distribution according to the type of green area corresponds to private use areas with $78.71 \%$, while public use areas amount to $21.29 \%$. At a subsystem level, if agriculture and livestock areas, as well as vacant lands are excluded - since they are considered urban growth reserve areas-, the housing subsystem has the largest percentage of green areas, while the sports subsystem has the least (Table 2).

At a subsystem level, public green areas have the lowest proportion; the sports subsystem (composed primarily of sport units) has the least surface, barely $1.07 \%$ of the total of green areas, followed by the recreation subsystem with $1.54 \%$ (primarily composed of neighborhood gardens, playgrounds and neighborhood parks) and thereafter, the natural subsystem with $2.99 \%$ (corresponding to green conservation areas). Meanwhile, the subsystem that has the highest percentage of public space is the roads subsystem with $9.93 \%$ (composed of vegetation on roadsides, roundabouts and sidewalks).

Concerning private green areas, the housing subsystem represents a fifth of the total $(22.04 \%)$, while the industrial, commercial and tourism subsystems represent just $5 \%$.

Regarding the amount and percentage of green areas in public and private spaces, a large disproportion is observed; on one hand, the supply of public spaces for recreation (Figure 7 ) and sports is just $2.61 \%$ of all green areas, representing an allocation of $1.10 \mathrm{~m}^{2}$ of green area per inhabitant; and on the other hand, in private spaces, residential green areas represent 22.04\% (Figure 8), which means $9.37 \mathrm{~m}^{2}$ of green area per inhabitant on average.

The other two subsystems of public type with the highest percentage of green areas are the road subsystem $(9.93 \%)$ and the subsystem of other public services $(5.76 \%)$ that integrates schools (Figure 9) and administrative buildings (Figure 10). 
Table 2: Green areas (GA) percentages and surfaces per capita per subsystem.

\begin{tabular}{|c|c|c|c|c|c|}
\hline Type & System & Subsystem & Surface $\left(\mathbf{m}^{2}\right)$ & $(\%)$ & $\begin{array}{l}\mathbf{m}^{2} \text { GA/ } \\
\text { Inhabitant }\end{array}$ \\
\hline \multirow{5}{*}{ 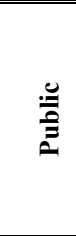 } & \multirow{3}{*}{$\begin{array}{l}\text { Green areas for public } \\
\text { services }\end{array}$} & Recreation & $444,624.62$ & 1.54 & 0.65 \\
\hline & & Sports & $309,414.32$ & 1.07 & 0.45 \\
\hline & & $\begin{array}{l}\text { Other public } \\
\text { services }\end{array}$ & $1^{\prime} 666,283,91$ & 5.76 & 2.45 \\
\hline & Functional green areas & Roads & 2'875,055.53 & 9.93 & 4.22 \\
\hline & $\begin{array}{l}\text { Natural and protected } \\
\text { green areas }\end{array}$ & Natural green areas & $864,159.27$ & 2.99 & 1.27 \\
\hline \multirow{7}{*}{ : } & \multirow{4}{*}{ Productive green areas } & Agricultural & $5 ' 439,174.18$ & 18.79 & $7.99 *$ \\
\hline & & Industrial & $513,198.48$ & 1.77 & 0.75 \\
\hline & & Commercial & $455,694.79$ & 1.57 & 0.67 \\
\hline & & Touristic & $493,517.70$ & 1.71 & 0.72 \\
\hline & \multirow{3}{*}{ Private green areas } & Housing & $6 ’ 379,090.22$ & 22.04 & 9.37 \\
\hline & & Mixed land uses & $805,651.87$ & 2.78 & 1.18 \\
\hline & & Vacant lots & $8^{\prime} 697,346.82$ & 30.05 & $12.78^{*}$ \\
\hline Total & & & $28^{\prime} 943,211.71$ & $100 \%$ & 45.52 \\
\hline
\end{tabular}

*Lots of land considered as urban growth reserves.

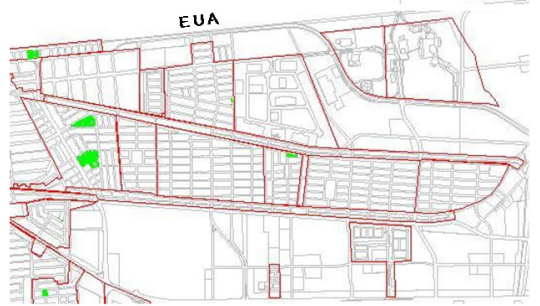

Figure 7: Recreation subsystem.

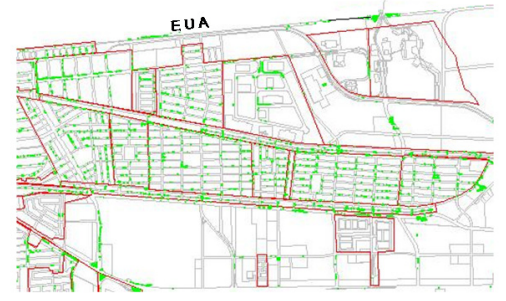

Figure 9: Road subsystem.

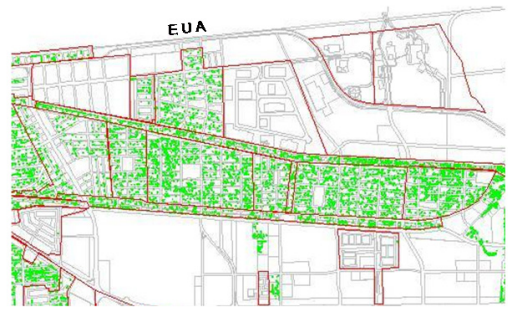

Figure 8: Housing subsystem.

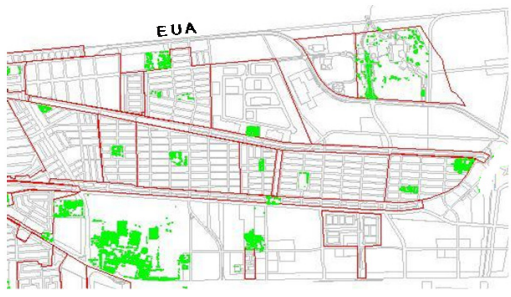

Figure 10: Other public services subsystem.

This disproportion of green areas for private use with respect to public green areas, points to the existing potential of private green areas from an environmental point of view, which are not considered in urban planning processes.

Regarding the use of multispectral imagery in the identification and classification of urban green areas, advantages such as accuracy are noteworthy, 
compared to other procedures. On one hand, the NDVI index, by detecting the photosynthetic activity of plants, registers surfaces with vegetation and eliminates the possible error of mistaking them with shadows, as with aerial photos; on the other hand, it avoids the overestimation in the quantification of the vegetation cover, as lands designated as parks or public gardens areas are quantified as green areas in urban development programs, but may be vacant and devoid of vegetation in reality. Also, the $2.6 \mathrm{~m}$ resolution of the images allowed to identify with great precision minimal surfaces of vegetation in housing, roads, medians and sidewalks, up to $6 \mathrm{~m}^{2}$ (such as a small tree canopy), which made possible to identify about 200,000 polygons of vegetation within the urban area.

Another advantage of identifying and classifying urban green areas by subsystem is that it allows the design of specific strategies in terms of financial resources and public participation in afforestation programs, by directly identifying all stakeholders instead of performing general afforestation strategies citywide.

Also, the geographical distribution of green areas classified by subsystem can be related to several variables, such as: Income levels of the population, neighborhood age, property values among others, to determine priorities and sectorial assessments to implement differentiated interventions in urban planning.

Finally, it is necessary to mention that the redesign of policies and legal framework is required in order to integrally incorporate all types of green areas in the urban planning process and contribute to sustainable development.

\section{References}

[1] Nowak, D.J. \& Crane D.E., Carbon storage and sequestration by urban tress in the USA. Environmental Pollution, 116, pp. 381-389, 2002.

[2] Muñoz-Vallés, S., Cambrollé, J., Figueroa-Luque, E., Luque, T., Niell, F.X. \& Figueroa, M.E., An approach to the evaluation and management of natural carbon sinks: From plant species to urban green systems. Urban Forestry \& Urban Greening, 12(4), pp. 450-453, 2013.

[3] Bencheikh, H. \& Rchid A., The effects of green spaces (Palme trees) on the microclimate in arid zones, case study: Ghardaia, Algeria. Energy Procedia, 18, pp. 10-20, 2012.

[4] Tratalos J., Fuller R., Warren P., Davies R. \& Gaston K., Urban form, biodiversity potential and ecosystem services. Landscape and Urban Planning, 83, pp. 308-317, 2007.

[5] Tzoulas, K., Korpela, K., Venn, S., Pelkonen, V.Y., Kazmierczak, A., Niemela, J. \& James, P., Promoting ecosystem and human health in urban areas using Green infrastructure: a literature review. Landscape and Urban Planning 81(3): pp. 167-178, 2007.

[6] Villeneuvea, P., Jerrett, M., Suc. J., Burnett, R., Chend H., Wheeler A. \& Goldbergf M., A cohort study relating urban green space with mortality in Ontario, Canada. Environmental Research, 115, pp. 51-58, 2012.

[7] McPherson, E. \& Johnson C., A Community Forestry Planning Process: Case Study of Citizen Participation. Landscape and Urban Planning, 15, pp. 185-194, 1988. 
[8] Jayiyae T., Goisetf, V. \& Mahumanif, B., Including the economic value of well-functioning urban ecosystems in financial decisions: Evidence from a process in Cape Town. Ecosystem Services, 2, pp. 38-44, 2012.

[9] Burden, D. Urban Street Trees, 22 Benefits Specific Applications. Glatting Jackson and Walkable Communities Inc., pp. 5, 2006. http://www.michigan.gov/documents/dnr/22_benefits_208084_7.pdf

[10] Vandermeulena, V., Verspechta, A., Vermeireb, B., Huylenbroecka, G. \& Gellyncka X., The use of economic valuation to create public support for green infrastructure investments in urban areas. Landscape and Urban Planning, 103, pp. 198-206, 2011.

[11] Miyasako K.E., Las áreas verdes en el contexto urbano de la ciudad de México, Tesis doctoral, RUA. Repositorio Institucional de la Universidad de Alicante, España, pp. 372-398, 2009.

http://rua.ua.es/dspace/bitstream/10045/24404/1/Tesis_Miyasako.pdf

[12] Sedesol, Sistema Normativo de Equipamiento Urbano: Manuales Técnicos, Subsecretaria de Desarrollo Urbano y Vivienda, Dirección General de Infraestructura y Equipamiento. México [Versión electrónica], 2001.

[13] Gobierno del Estado de Baja California, Reglamento de Fraccionamientos del Estado de Baja California, Periódico Oficial del Estado de Baja California,10 de Abril, Sección I, Tomo LXXVIII, 1971.

[14] XVIII Ayuntamiento de Mexicali, Reglamento de áreas verdes para el Municipio de Mexicali, Baja California, Periódico Oficial del Estado de Baja California, 06 de mayo, 2005.

[15] XVIII Ayuntamiento de Tijuana, Reglamento de Forestación para el Municipio de Tijuana, Baja California. Periódico Oficial del Estado de Baja California, 23 de septiembre, 2005.

[16] XVIII Ayuntamiento de Ensenada, Reglamento de parques y jardines del municipio de Ensenada, Baja California. Periódico Oficial del Estado de Baja California, 15 Tomo CXV, 11 de Abril, 2008.

[17] Peña, S.C., Metodología para la planificación de áreas verdes urbanas: El caso de Mexicali, Baja California, Universidad Autónoma de Baja California, México, pp. 19-71, 2011.

[18] Ray, T.W. A FAQ on Vegetation. Remote Sensing, California Institute of Technology, http://www.yale.edu/ceo/Documentation/rsvegfaq.html

[19] Instituto Municipal de Investigación y Planeación Urbana de Mexicali, Programa de Desarrollo Urbano de Centro de Población de Mexicali B.C. 2025, Versión abreviada para consulta, [versión electrónica] 2005.

[20] XVIII Ayuntamiento de Mexicali, Inventario de las áreas verdes dependientes del H. Ayuntamiento de Mexicali, B.C.: Jardines, isletas, triángulos, glorietas, camellones y parques, y áreas nuevas. Dirección de Obras y Servicios Públicos Municipales, Departamento de áreas verdes (Archivo en Excel), 2004.

[21] Secretaria de Infraestructura y Desarrollo Urbano, Inventario de equipamiento educativo. [Archivo electrónico en Mapinfo], Agosto 2004. 